University of Nebraska - Lincoln

DigitalCommons@University of Nebraska - Lincoln

Publications, Agencies and Staff of the U.S.

Department of Commerce

U.S. Department of Commerce

2002

\title{
Chemical contaminants in juvenile gray whales (Eschrichtius robustus) from a subsistence harvest in Arctic feeding grounds
}

\author{
Karen L. Tilbury \\ Environmental Conservation Division, Northwest Fisheries Science Center, National Marine Fisheries \\ Service, National Oceanic and Atmospheric Administration \\ John E. Stein \\ Environmental Conservation Division, Northwest Fisheries Science Center, National Marine Fisheries \\ Service, National Oceanic and Atmospheric Administration \\ Cheryl A. Krone \\ Environmental Conservation Division, Northwest Fisheries Science Center, National Marine Fisheries \\ Service, National Oceanic and Atmospheric Administration \\ Robert L. Brownell Jr. \\ Southwest Fisheries Science Center, National Marine Fisheries Service, National Oceanic and \\ Atmospheric Administration, rlbcetacea@aol.com \\ S.A. Blokhin \\ Pacific Research Institute of Fisheries and Oceanography (TINRO), 690600 Vladivostok, Russia \\ Elllow this and additionahworksat: https://digitalcommons.unl.edu/usdeptcommercepub \\ Part of the Environmental Sciences Commons
}

Tilbury, Karen L.; Stein, John E.; Krone, Cheryl A.; Brownell, Robert L. Jr.; Blokhin, S.A.; Bolton, Jennie L.; and Ernest, Don W., "Chemical contaminants in juvenile gray whales (Eschrichtius robustus) from a subsistence harvest in Arctic feeding grounds" (2002). Publications, Agencies and Staff of the U.S. Department of Commerce. 79.

https://digitalcommons.unl.edu/usdeptcommercepub/79

This Article is brought to you for free and open access by the U.S. Department of Commerce at DigitalCommons@University of Nebraska - Lincoln. It has been accepted for inclusion in Publications, Agencies and Staff of the U.S. Department of Commerce by an authorized administrator of DigitalCommons@University of Nebraska - Lincoln. 
Authors

Karen L. Tilbury, John E. Stein, Cheryl A. Krone, Robert L. Brownell Jr., S.A. Blokhin, Jennie L. Bolton, and Don W. Ernest 


\title{
CHEMOSPHERE
}

\section{Chemical contaminants in juvenile gray whales (Eschrichtius robustus) from a subsistence harvest in Arctic feeding grounds}

\author{
Karen L. Tilbury ${ }^{a, *}$, John E. Stein ${ }^{a}$, Cheryl A. Krone ${ }^{a}$, \\ Robert L. Brownell Jr. ${ }^{\mathrm{b}}$, S.A. Blokhin ${ }^{\mathrm{c}}$, Jennie L. Bolton ${ }^{\mathrm{a}}$, \\ Don W. Ernest ${ }^{a}$ \\ ${ }^{a}$ Environmental Conservation Division, Northwest Fisheries Science Center, National Marine Fisheries Service, \\ National Oceanic and Atmospheric Administration, 2725 Montlake Boulevard East, Seattle, WA 98112, USA \\ ${ }^{\mathrm{b}}$ Southwest Fisheries Science Center, National Marine Fisheries Service, National Oceanic and Atmospheric Administration, \\ 8604 LaJolla Shores Drive, LaJolla, CA 92038, USA \\ c Pacific Research Institute of Fisheries and Oceanography (TINRO), 690600 Vladivostok, Russia
}

Received 31 May 2001; received in revised form 20 August 2001; accepted 25 August 2001

\begin{abstract}
Gray whales are coastal migratory baleen whales that are benthic feeders. Most of their feeding takes place in the northern Pacific Ocean with opportunistic feeding taking place during their migrations and residence on the breeding grounds. The concentrations of organochlorines and trace elements were determined in tissues and stomach contents of juvenile gray whales that were taken on their Arctic feeding grounds in the western Bering Sea during a Russian subsistence harvest. These concentrations were compared to previously published data for contaminants in gray whales that stranded along the west coast of the US during their northbound migration. Feeding in coastal waters during their migrations may present a risk of exposure to toxic chemicals in some regions. The mean concentration (standard error of the mean, SEM) of $\sum$ PCBs [1400 (130) ng/g, lipid weight] in the blubber of juvenile subsistence whales was significantly lower than the mean level [27000 $(11000) \mathrm{ng} / \mathrm{g}$, lipid weight] reported previously in juvenile gray whales that stranded in waters off the west coast of the US. Aluminum in stomach contents of the subsistence whales was high compared to other marine mammal species, which is consistent with the ingestion of sediment during feeding. Furthermore, the concentrations of potentially toxic chemicals in tissues were relatively low when compared to the concentrations in tissues of other marine mammals feeding at higher trophic levels. These chemical contaminant data for the subsistence gray whales substantially increase the information available for presumably healthy animals. (C) 2002 Elsevier Science Ltd. All rights reserved.
\end{abstract}

Keywords: Gray whale; Organochlorine; PCBs; Element; Baleen whale; Bering Sea

\footnotetext{
* Corresponding author. Tel.: +1-206-860-3338; fax: +1-206860-3335.

E-mail address: karen.tilbury@noaa.gov (K.L. Tilbury).
}

\section{Introduction}

Gray whales (Eschrichtius robustus) make an annual round-trip migration between their breeding grounds in subtropical waters (e.g., off Baja California and the southern Gulf of California) and their predominant feeding grounds in the northern Pacific Ocean. The 
Arctic feeding grounds provide an abundance of food and most likely greater quantities than in other areas visited during their migration (Highsmith and Coyle, 1992; Moore et al., 2000). Although the majority of feeding is in the Bering and Chukchi Seas in Alaska, some animals spend extended periods in the spring and summer opportunistically feeding in the coastal waters of Washington, California, Oregon and British Columbia (Rice and Wolman, 1971; Patten and Samaras, 1977; Calambokidis et al., 1991; Mallonee, 1991; Darling, 1984; Nerini, 1984; Sumich, 1984; Calambokidis, 1992). The gray whale feeds primarily on benthic prey, such as ampeliscid amphipods (Ampelisca macrocephala), using suction to engulf sediments and prey from the bottom, then filtering out water and sediment through their baleen plates and ingesting the remaining prey. This unique feeding strategy among baleen whales often results in the ingestion of sediment and other bottom materials (Rice and Wolman, 1971; Nerini, 1984). Thus, exposure to sediment-associated contaminants is possible if gray whales feed in coastal areas containing sediment and benthic invertebrates contaminated by anthropogenic compounds.

The body mass, overall fat content, girth and blubber thickness of the gray whales are significantly higher during the southbound migration to their breeding grounds than during the return northbound migration (Rice and Wolman, 1971). The composition of blubber, especially the amount of lipids, and blubber thickness can also be affected by the nutritive condition of the animal (Aguilar and Borrell, 1990). Early population studies on Antarctic baleen whales (Mackintosh and Wheeler, 1929; Mizue and Murata, 1951; Nishiwaki and Ohe, 1951; Slijper, 1954; Ash, 1956) showed that variation in blubber thickness is related to nutritional status and has been widely used as a condition index for cetaceans (Aguilar and Borrell, 1990).

Organochlorine (OC) pollutants are among the most widespread and persistent chemical contaminants present in the marine environment. These pollutants, because of their lipophilicity and resistance to metabolism, may bioaccumulate in aquatic organisms over time, particularly in the lipid-rich tissues of marine mammals (Varanasi et al., 1992). This is especially true in males because they do not eliminate OCs as females can do through gestation and lactation (Wagemann and Muir, 1984; Subramanian et al., 1988). Toxic and essential elements found in gray whales are also of concern because of their toxicological significance and possible accumulation in certain organs (e.g., kidney, brain) of marine mammals. For example, mercury is nephrotoxic in mammals and it has been suggested that aluminum may alter brain function (Goyer, 1986).

In the current study, tissue samples were collected from apparently healthy juvenile gray whales from the eastern north Pacific stock that were taken on their
Arctic feeding grounds, a relatively pristine area in the western Bering Sea, during a Russian subsistence harvest. Concentrations of OCs (e.g., PCBs, DDTs, hexachlorobenzene), selected non-essential, potentially toxic elements (e.g., mercury, cadmium) and essential elements (e.g., selenium), along with percent lipid, were determined in tissue samples and stomach contents of these animals. Because gray whales feed on benthic organisms, analyses of stomach contents for contaminants (e.g., selected elements) can provide insight into the dietary sources and concentrations of these compounds. These data considerably increase the database for the concentrations of contaminants in gray whales that have not stranded (i.e. supposedly healthy animals).

\section{Methods}

\subsection{Field sampling}

Samples of blubber, liver, kidney, stomach contents, brain and muscle were collected from 22 gray whales taken from the eastern north Pacific stock during a Russian subsistence harvest in late September and October 1994 in the Bering Sea (Fig. 1). It should be noted that complete sets of tissue samples were not available from each whale (Table 1). The subsistence whales were necropsied within $24 \mathrm{~h}$ of death. The tissue samples were immediately stored on ice, subsequently frozen in a -20 ${ }^{\circ} \mathrm{C}$ freezer, shipped with dry ice to the Northwest Fisheries Science Center and stored at $-80^{\circ} \mathrm{C}$ until chemical analyses.

\subsection{Analytical procedures}

\subsubsection{Organochlorines}

The gray whale samples taken during the subsistence harvest were analyzed for OCs and percent lipid (Krahn et al., 1988; Sloan et al., 1993). Briefly, tissue (1-3 g) and stomach contents $(1-5 \mathrm{~g})$ were macerated with sodium sulfate and methylene chloride. The methylene chloride extract was filtered through a column of silica gel and alumina and the extract concentrated for further cleanup. The cleanup was done using size exclusion chromatography with high performance liquid chromatography (HPLC). The original analytical method was modified slightly by adjusting the flow rate to $5 \mathrm{ml} / \mathrm{min}$ to facilitate the cleanup for the lipid-rich blubber tissue and then a fraction containing the OCs was collected. The HPLC fraction was exchanged into hexane and the extracts were analyzed for OCs using a Hewlett-Packard 5890 capillary gas chromatograph equipped with an electron capture detector (GC/ECD). A $60 \mathrm{~m}$ DB-5 capillary column $(0.25 \mathrm{~mm}$ ID, J\&W Scientific) was used. The sample extract $(3 \mu \mathrm{l})$ was injected splitless 


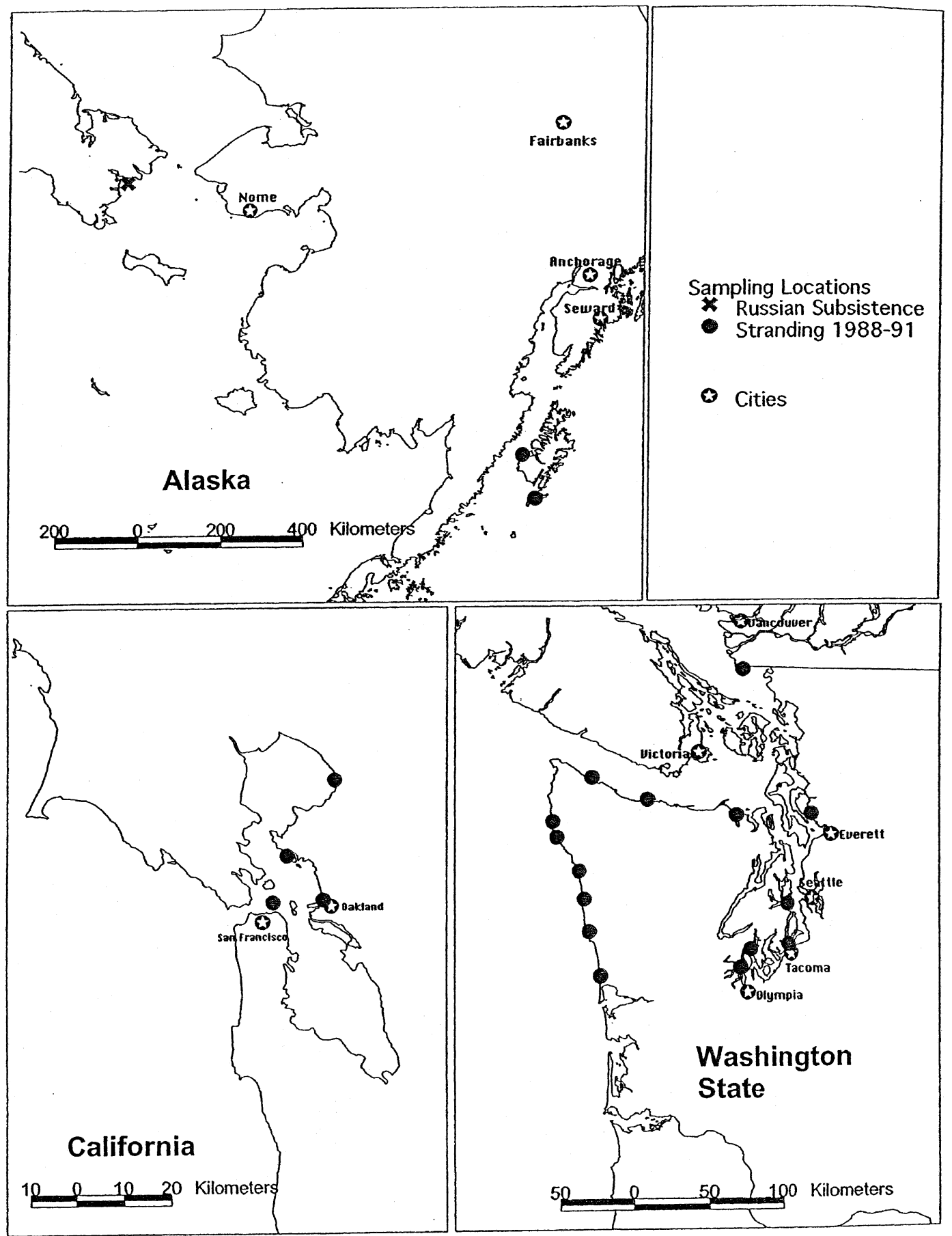

Fig. 1. Locations of the Russian gray whale subsistence harvest, as well as, gray whale collection sites in Alaska, California and Washington (adapted from Krahn et al. (2001)).

(split valve opened $0.5 \mathrm{~min}$, oven temperature $50^{\circ} \mathrm{C}$ held $1 \mathrm{~min}$ ). Oven temperature was programmed to $315^{\circ} \mathrm{C}$ at $4{ }^{\circ} \mathrm{C} / \mathrm{min}$. Identification of selected individual OCs was confirmed by retention time comparison to standards and by mass spectrometry (GC/MS) with selected ion monitoring (Sloan et al., 1993). 
Table 1

Subsistence gray whale specimen number, sex, length, and tissues analyzed $^{\mathrm{a}}$

\begin{tabular}{|c|c|c|c|}
\hline $\begin{array}{l}\text { Specimen } \\
\text { number }\end{array}$ & Sex & $\begin{array}{l}\text { Length } \\
(\mathrm{cm})\end{array}$ & Tissues analyzed $^{\mathrm{b}}$ \\
\hline 06 & Female & 770 & Blubber \\
\hline 13 & Female & 780 & Liver \\
\hline 20 & Female & 800 & Blubber, liver \\
\hline 23 & Female & 800 & Blubber, liver \\
\hline 14 & Female & 830 & $\begin{array}{l}\text { Blubber, liver, kidney, } \\
\text { brain, muscle, stomach } \\
\text { contents }\end{array}$ \\
\hline 08 & Female & 840 & Liver \\
\hline 22 & Female & 840 & Blubber, liver \\
\hline 02 & Female & 850 & Liver \\
\hline 19 & Female & 860 & $\begin{array}{l}\text { Blubber, liver, kidney, } \\
\text { brain }\end{array}$ \\
\hline 07 & Female & 870 & Blubber \\
\hline 10 & Female & 870 & Blubber \\
\hline 01 & Female & 880 & Blubber \\
\hline 18 & Female & 930 & Blubber, liver \\
\hline 27 & Female & 930 & Blubber \\
\hline 17 & Female & 950 & $\begin{array}{l}\text { Blubber, liver, kidney, } \\
\text { brain, muscle, stomach } \\
\text { contents }\end{array}$ \\
\hline 25 & Female & 1160 & Blubber \\
\hline 26 & Male & 780 & Blubber, kidney, brain \\
\hline 03 & Male & 800 & Liver \\
\hline 21 & Male & 800 & $\begin{array}{l}\text { Blubber, liver, kidney, } \\
\text { brain }\end{array}$ \\
\hline 28 & Male & 860 & $\begin{array}{l}\text { Blubber, liver, kidney, } \\
\text { brain }\end{array}$ \\
\hline 11 & Male & 880 & Liver \\
\hline 05 & Male & 890 & Blubber, muscle \\
\hline
\end{tabular}

${ }^{\mathrm{a}}$ All animals were juveniles and tissue samples were collected from September 30, 1994 through October 26, 1994.

${ }^{\mathrm{b}}$ Blubber, liver, kidney, stomach contents, and brain were also collected from 22 stranded gray whales along the Pacific coasts (Fig. 1) between March 1988 and June 1992 and included juveniles and adults. The mean (standard error) length [1100 $(97) \mathrm{cm}$ ] was significantly higher than that for the subsistence animals [860 (18) cm]. The stranded animals included six females $[1000(95) \mathrm{cm}]$ and 14 males $[1300(30) \mathrm{cm}]$; the sex and length of two whales were unknown (Varanasi et al., 1993, 1994).

The OCs are reported herein as follows: " $\sum$ PCBs" refers to the sum of the concentrations of 17 congeners $(18,28,44,52,66,101,105,118,128,138,153,170$, $180,187,195,206,209)$ times two. The congeners are numbered using the accepted system as developed by

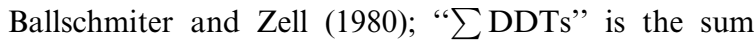
of the concentrations of $o, p^{\prime}$-DDD, $p, p^{\prime}$-DDD, $o, p^{\prime}$ DDE, $p, p^{\prime}$-DDE, $o, p^{\prime}$-DDT and $p, p^{\prime}$-DDT; and the " $\sum$ chlordanes" is the sum of the concentrations of cischlordane, oxychlordane, trans-non-achlor, heptachlor and heptachlor epoxide. All OC concentrations were reported as ng/g, wet weight or ng/g, lipid weight.

\subsubsection{Elements}

Samples of liver, kidney, brain and stomach contents were analyzed for selected elements and percent solids (Robisch and Clark, 1993). Briefly, thawed tissue (1-2 g) was freeze-dried and then digested with $10 \mathrm{ml}$ of concentrated nitric acid for $2 \mathrm{~h}$ at room temperature and subsequently heated in a microwave oven in sealed Teflon vessels. The digests were then treated with $4 \mathrm{ml}$ hydrogen peroxide to destroy organic matter and further heating in the microwave oven. The digests were diluted with deionized water and the concentrations of elements were determined by graphite furnace atomic absorption (arsenic, lead, nickel, selenium) inductively coupled argon plasma optical emission spectroscopy (aluminum, cadmium, chromium, copper, iron, manganese, silver, vanadium, zinc) and cold vapor atomic absorption (mercury). The concentrations of the elements were reported as $\mathrm{ng} / \mathrm{g}$, wet weight.

\subsubsection{Lipids}

To determine total non-volatile extractables (reported as percent total lipids) for the samples analyzed by $\mathrm{GC} / \mathrm{ECD}$, an aliquot of the initial methylene chloride extract of tissue was filtered through filter paper containing approximately $5 \mathrm{~g}$ of diatomaceous earth as a filtering aid and the solvent removed from each sample using a rotary evaporator. After the solvent was removed, the mass of lipid was determined. The percent lipid was calculated by dividing the mass of lipid by the original sample wet weight and multiplying by 100 (Varanasi et al., 1993, 1994).

\subsection{Quality assurance}

Quality control procedures for OCs and elements included analyses of standard reference materials (SRMs), a National Institute of Standards and Technology (NIST) control whale blubber sample, certified calibration standards, method blanks, solvent blanks and replicate samples. The reference material analyzed with OCs was SRM 1945 Whale Tissue Homogenate. The reference materials for elements included SRM 1566a (oyster tissue) from NIST and DOLT-2 (dogfish liver), DORM-2 (dogfish muscle), LUTS-1 (non-defatted lobster hepatopancreas) and TORT-2 (lobster hepatopancreas) from the National Research Council of Canada. The standards are discussed in detail in the references cited. Acceptance criteria for analyses of control materials were similar to those NIST uses for its tissue intercomparison exercises. Concentrations of analytes were within $\pm 35 \%$ from the upper and lower limits of the $95 \%$ confidence interval of NIST concentrations. Replicate analyses were within $35 \%$ of the relative standard deviation and surrogate recoveries were 
from $60 \%$ to $130 \%$. Quality assurance results (e.g., analyses of SRMs, replicates, method blanks) met these laboratory criteria.

\subsection{Statistical analysis}

The data were $\log$ transformed $[\log (x+1)]$ to reduce deviations from normality (i.e., to reduce heteroscedasticity in the variances). Analysis of variance (ANOVA) and Student's $t$-test were used to compare differences in mean concentrations of OCs between juvenile Russian subsistence gray whales and juvenile gray whales that stranded in 1988-1991. Analysis of variance was completed using SuperANOVA Statistical Software (Abacus Concepts, 1989). Differences between means were considered significant at $a \leqslant 0.05$. Results from statistical analyses were very similar whether concentrations were expressed on a wet weight or lipid weight basis.

\section{Results and discussion}

Specific age data for the subsistence whales were not available, therefore length was used as a surrogate to estimate age class. It has been estimated that adult gray whales are sexually mature at approximately $1200 \mathrm{~cm}$ in length (Norman et al., 2000). The sampled animals were all juveniles with a [mean \pm SEM] length of $860 \pm 18$ $\mathrm{cm} ; 870 \pm 23 \mathrm{~cm}$ for the 16 females and $840 \pm 19 \mathrm{~cm}$ for the six males (Table 1). This group of gray whales from which tissue samples were collected is unusual because all the animals were juveniles, therefore, the influence of length (i.e., age and developmental stage) on the concentrations of contaminants is minimized. This is significant because mature female whales may transfer contaminants during gestation and lactation, whereas males may continue to accumulate OCs with increasing age (Wagemann and Muir, 1984; Subramanian et al., 1988). The majority of contaminant data in the literature is from whale groups that consist of animals from various age classes. For example, the lengths of the previously sampled stranded whales (Varanasi et al., 1993, 1994) ranged from 790 to $1300 \mathrm{~cm}$ with a mean length of $1120 \pm 37 \mathrm{~cm}$; the SEM was approximately two times that of the SEM for the subsistence whales (range; 770$950 \mathrm{~cm}$ with one whale $1160 \mathrm{~cm}$ ).

\subsection{Lipids}

Mean lipid concentrations of blubber, liver, kidney and muscle as well as stomach contents of juvenile subsistence gray whales are shown in Table 2 . We compared the lipid content of the tissues of the juvenile subsistence animals with the lipid concentrations of the same tissues in juvenile gray whales that stranded in 1988-1991. The mean lipid levels in the blubber $(48 \pm 5.2 \%)$ and stomach contents $(2.8 \pm 0.1 \%)$ of the subsistence animals were higher than the mean lipid concentrations of blubber $(13 \pm 6.0 \%)$ and stomach contents $(1.2 \pm 0.3 \%)$ in the $1988-1991$ stranded whales (Varanasi et al., 1993, 1994). The higher lipid content of blubber of the subsistence whales may be attributed to the increased lipid stores in these animals after feeding in the Bering and Chukchi Seas during the summer. In contrast, the tissues of the stranded whales were collected after the breeding season in Baja California, when their lipid stores are more likely to be depleted. Rice and Wolman (1971) report that northbound migrating (postbreeding) whales have decreased weights, girths, blubber thickness and oil content compared to southbound migrants (post-feeding). In addition, some leaching of oil from the blubber of the stranded whales may have occurred either before the sample was taken, as some of the animals were necropsied several days after death, or before the sample was frozen.

\subsection{Organochlorines}

The mean concentrations (based on wet and lipid weights) of OCs in the juvenile gray whales are shown in Table 2. We found much higher mean concentrations (based on wet weight) of OCs in the blubber of juvenile gray whales compared to the mean levels in the liver, brain, kidney and muscle (Table 2). Accumulation of lipophilic OCs among various tissues of marine mammals may be related to lipid content as well as the type of lipid classes comprising each tissue (Aguilar, 1985). For example, when we compared the mean OC levels (based on lipid weight) among the various tissues of the whales, we found the mean concentrations to be more comparable among these tissues except brain. In this tissue, the mean OC concentrations (based on lipid weight) were lower than the mean levels in blubber, liver, kidney and muscle. The lipid in the brain of marine mammals consists of high proportions of polar phospholipids and total cholesterol and OCs partition less into these polar lipids in comparison to the more lipophilic neutral lipids (Fukushima and Kawai, 1980; Aguilar, 1985; Tilbury et al., 1997). In contrast, a large proportion of blubber is comprised of neutral lipids (i.e., triglycerides, non-esterified fatty acids), which favors the accumulation of lipophilic contaminants such as PCBs and DDTs (Kawai et al., 1988).

There were no differences in the mean concentrations of OCs between the male and female juvenile subsistence whales (Table 3). Previous marine mammal contaminant studies have shown that the concentrations of OCs in juvenile animals of both sexes increase until sexual 
Table 2

Concentrations [mean (SEM)] of OCs, elements and percent lipid in tissues of subsistence gray whales

\begin{tabular}{|c|c|c|c|c|c|c|}
\hline & $\begin{array}{l}\text { Blubber } \\
n=17\end{array}$ & $\begin{array}{l}\text { Liver } \\
n=14\end{array}$ & $\begin{array}{l}\text { Kidney } \\
n=6\end{array}$ & $\begin{array}{l}\text { Brain } \\
n=6\end{array}$ & $\begin{array}{l}\text { Muscle } \\
n=3\end{array}$ & $\begin{array}{l}\text { Stomach contents } \\
n=2\end{array}$ \\
\hline \multicolumn{7}{|c|}{ Wet weight (ng/g wet weight) } \\
\hline Hexachlorobenzene & $230(32)^{\mathrm{a}}$ & $24(4)$ & $8(1)$ & $9(2)$ & $2(1)$ & $1(0.1)$ \\
\hline$\sum$ Chlordanes & $140(20)$ & $5(1)$ & $2(0.5)$ & $2(1)$ & $1(0.2)$ & $0.6(0.3)$ \\
\hline$\sum \mathrm{DDTs}$ & $150(32)$ & $3(0.4)$ & $1(0.2)$ & $1(0.3)$ & $1(0.2)$ & $1(0.1)$ \\
\hline$\sum \mathrm{PCBs}$ & $630(83)$ & $22(2)$ & $16(2)$ & $21(2)$ & $9(2)$ & $24(7)$ \\
\hline \multicolumn{7}{|c|}{ Lipid weight (ng/g lipid) } \\
\hline Hexachlorobenzene & $530(77)$ & $890(160)$ & $450(49)$ & $130(14)$ & $580(310)$ & $36(1)$ \\
\hline$\sum$ Chlordanes & $320(43)$ & $160(25)$ & $94(4)$ & $32(7)$ & $280(97)$ & $20(20)$ \\
\hline$\sum \mathrm{DDTs}$ & $330(53)$ & $120(15)$ & $46(9)$ & $15(3)$ & $340(63)$ & $17(17)$ \\
\hline$\sum \mathrm{PCBs}$ & $1400(130)$ & $910(97)$ & $930(63)$ & $340(47)$ & $2400(610)$ & $850(260)$ \\
\hline \multirow[t]{2}{*}{ Percent lipid } & $48(5.2)$ & $2.8(0.3)$ & $1.8(0.1)$ & $6.9(1.1)$ & $0.4(0.1)$ & $2.8(0.1)$ \\
\hline & $\begin{array}{l}\text { Blubber } \\
\text { na }^{\mathrm{b}}\end{array}$ & $\begin{array}{l}\text { Liver } \\
n=5\end{array}$ & $\begin{array}{l}\text { Kidney } \\
n=6\end{array}$ & $\begin{array}{l}\text { Brain } \\
n=6\end{array}$ & $\begin{array}{l}\text { Muscle } \\
\text { na }\end{array}$ & $\begin{array}{l}\text { Stomach contents } \\
n=2\end{array}$ \\
\hline \multicolumn{7}{|c|}{ Wet weight (ng/g wet weight) } \\
\hline Aluminum & & $4200(2700)$ & $2800(1700)$ & $1000(98)$ & & $3900000(370000)$ \\
\hline Arsenic & & $320(28)$ & $1500(430)$ & $53(11)$ & & $6100(200)$ \\
\hline Cadmium & & $210(40)$ & $590(110)$ & $100(10)$ & & $680(13)$ \\
\hline Chromium & & $290(19)$ & $220(10)$ & $200(20)$ & & $3900(37)$ \\
\hline Copper & & $16000(3400)$ & $2600(89)$ & $2500(150)$ & & $3000(1700)$ \\
\hline Iron & & $340000(67000)$ & $75000(7800)$ & $23000(1400)$ & & $3400000(260000)$ \\
\hline Manganese & & $3100(180)$ & $1000(42)$ & $340(29)$ & & $33000(5900)$ \\
\hline Mercury & & $160(61)$ & $34(1)$ & $22(2)$ & & $46(2)$ \\
\hline Nickel & & $39(14)$ & $36(8)$ & $85(66)$ & & $1700(320)$ \\
\hline Lead & & $60(13)$ & $28(5)$ & $14(3)$ & & $980(150)$ \\
\hline Selenium & & $1100(150)$ & $1800(200)$ & $190(16)$ & & $170(12)$ \\
\hline Silver & & $310(64)$ & $1(0.1)$ & $11(2)$ & & $85(9)$ \\
\hline Vanadium & & $520(55)$ & $230(31)$ & $\mathrm{Nd}$ & & $6500(750)$ \\
\hline Zinc & & $28000(1900)$ & $18000(950)$ & $8600(520)$ & & $9800(1800)$ \\
\hline
\end{tabular}

$\mathrm{Nd}=$ not detected.

${ }^{a}$ Mean values (SEM) were calculated using one-half the detection limit for any analytes that were not detected.

${ }^{\mathrm{b}}$ The tissue was not analyzed (na).

maturity (Aguilar and Borrell, 1988; Kuehl and Haebler, 1995; Krahn et al., 1999; Tilbury et al., 1999). Males continue to accumulate these lipophilic contaminants throughout their lives. In contrast, a reproductive female's OC levels decrease due to maternal transfer of lipophilic OCs to her offspring during gestation and lactation (Wagemann and Muir, 1984; Aguilar and Borrell, 1994; Beckmen et al., 1999; Krahn et al., 1999). Based on the results of these previous studies, we did not expect to find differences in concentrations of OCs between male and female juvenile gray whales in this study since they were from the same age class (juvenile).

Few chemical contaminant data are available for gray whales. Wolman and Wilson (1970) reported the presence of DDTs in 6 of 23 gray whales that stranded off San Francisco, California during both their northern and southern migrations. Schaffer et al. (1984) reported concentrations of DDTs $(470 \mathrm{ng} / \mathrm{g}$, wet weight) in blubber of a gray whale stranded in southern California in 1976; $\sum$ PCBs was $<230 \mathrm{ng} / \mathrm{g}$ wet weight. Varanasi et al. $(1993,1994)$ reported chemical contaminant data for 22 gray whales that stranded along the west coast of the US from 1988 through 1991. We compared the OC levels in the juvenile subsistence whales with juvenile whales that stranded from 1988 to 1991 and found that the juvenile stranded animals (Varanasi et al., 1993, 1994) contained significantly higher mean concentrations of $\sum$ PCBs and $\sum$ DDTs than did juvenile subsistence animals (Fig. 2). Although the differences in OC concentrations between the subsistence and stranded juvenile whales may be due to diet or feeding areas, it is more likely that the higher OC concentrations are due to the retention of these chemical contaminants in blubber when lipid stores are mobilized for energy and the level of total lipid decreases in blubber. If the differences in OC levels were due to diet or feeding, we would expect to find higher concentrations of OCs in gray whales that feed near urban areas (e.g., Puget Sound, WA) than the 
Table 3

Concentrations [mean (SEM)] of OCs and percent lipid in blubber of gray whale

\begin{tabular}{lllll}
\hline & \multicolumn{2}{l}{ ng/g lipid weight } & & Percent lipid \\
\cline { 2 - 4 } & $\sum$ DDTs & $\sum$ PCBs & Hexachlorobenzene & \\
\hline Subsistence & & & & \\
Juvenile $(n=17)^{\mathrm{a}}$ & $330(53)^{\mathrm{b}}$ & $1400(130)$ & $530(77)$ & $48(5.2)$ \\
Female $(n=13)$ & $360(66)$ & $1400(140)$ & $550(97)$ & $48(6.1)$ \\
Male $(n=4)$ & $200(38)$ & $1200(360)$ & $470(89)$ & $48(11)$ \\
Stranded & & & & $9.7(4.8)$ \\
Female $(n=6)$ & $2800(1000)$ & $11000(3500)$ & $4400(1200)$ & $9.1(5.1)$ \\
Male $(n=14)$ & $39000(23000)$ & $74000(38000)$ & $31000(22000)$ & $2.0(1.0)$ \\
Unknown $(n=2)$ & $5900(4600)$ & $21000(6400)$ & $2100(330)$ & $13(6.0)$ \\
Juvenile $($ female $=4$, male $=8)$ & $11000(4300)$ & $27000(11000)$ & $7300(2800)$ & \\
\hline
\end{tabular}

${ }^{a}$ The juveniles include the female and male subsistence animals below.

${ }^{\mathrm{b}}$ Mean values (SEM) were calculated using one-half the detection limit for any analytes that were not detected.

${ }^{\mathrm{c}}$ Varanasi et al. (1993, 1994).

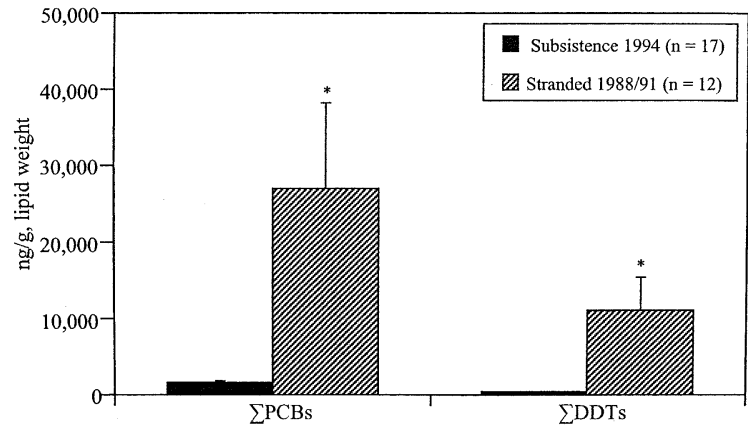

Fig. 2. Mean concentrations (ng/g, lipid weight) of $\sum \mathrm{PCBs}$ and $\sum$ DDTs in blubber of subsistence 1994 and stranded 1988-1991 juvenile gray whales. Asterisk indicates that the mean concentration of OCs in stranded whales is significantly higher $(p \leqslant 0.05)$ than the corresponding value for subsistence whales of the same age class (juvenile) by Student's $t$-test.

OC levels in animals that feed in more pristine waters (e.g., Alaska). Varanasi et al. $(1993,1994)$ showed that there were no striking differences in blubber concentrations of OCs in gray whales based on stranding location, even though the animals stranded at several different geographical areas that showed a wide range of OC concentrations in sediment (Varanasi et al., 1993, 1994). However, it is not known if these stranded whales had been feeding in the areas where they stranded.

We compared the concentrations of $\sum$ PCBs and $\sum$ DDTs in tissues from the subsistence gray whales to the values for cetaceans from other studies (O'Shea and Brownell, 1994). The subsistence gray whales had similar or lower concentrations (wet weight) of these contaminants than other mysticetes. For example, the concentrations of $\sum$ PCBs and $\sum$ DDTs range from $<10$ to 7000 and $<10$ to $23000 \mathrm{ng} / \mathrm{g}$, wet weight, respectively, in blubber of humpback (Megaptera novaeangliae), fin (Balaenoptera physalus) and minke (Balaenoptera acutorostrata) whales (Wagemann and Muir, 1984). The concentrations of $\sum$ PCBs and $\sum$ DDTs in blubber of the gray whales in the present study ranged from 110 to 1300 and 30 to $540 \mathrm{ng} / \mathrm{g}$, wet weight, respectively. In contrast, the concentrations of $\sum$ PCBs and $\sum$ DDTs in toothed (odontoceti) marine mammal species that feed in coastal waters, such as harbor porpoise (Phocoena phocoena), can have blubber concentrations of $23000 \pm 5800$ and $9100 \pm 1500 \mathrm{ng} / \mathrm{g}$, wet weight, respectively (Tilbury et al., 1997). In bottlenose dolphin (Tursiops truncatus) from the Gulf of Mexico, the concentrations of $\sum$ PCBs and $\sum$ DDTs in blubber can be as high as $72000 \mathrm{ng} / \mathrm{g}$ and $110000 \mathrm{ng} / \mathrm{g}$ wet weight, respectively (unpublished data).

\subsection{Elements}

The distribution of selected elements among tissues (liver, kidney, brain) and stomach contents of the whales was more variable when compared to the distribution of OCs (Table 2). The mean concentration of mercury (a non-essential element along with arsenic, cadmium and lead) in liver, was approximately five times the concentration found in kidney and eight times the concentration in brain (Table 2). The mean concentration of cadmium was highest in kidney where it is known to preferentially accumulate; the mean concentration in liver was approximately three times less than the concentration in kidney (Table 2). This is consistent with previous studies showing that the ratio of renal to hepatic cadmium in marine mammals commonly varies from about two to five (Wagemann and Muir, 1984; Fujise et al., 1988; Wagemann et al., 1990; Meador et al., 1993).

The mean concentrations of certain elements (aluminum, arsenic, chromium, iron, manganese, nickel, 
vanadium) were higher in stomach contents of gray whales than in the other tissues (Table 2). The higher concentrations of certain elements in stomach contents are consistent with ingestion of sediment as part of the natural feeding habits of gray whales (Haley, 1986). The lower concentrations of elements in tissues suggest that chromium, nickel, lead and vanadium, for example, are not readily bioavailable from sediment.

The relatively high concentrations of aluminum in liver, kidney and brain of gray whales indicate bioaccumulation of this non-essential element in these tissues. In contrast, aluminum concentrations $(<600 \mathrm{ng} / \mathrm{g}$, wet weight) in Alaskan bowhead whale liver (Krone et al., 1999) were considerably less than the concentrations in the subsistence gray whale liver $(4100 \pm 2700 \mathrm{ng} / \mathrm{g}$, wet weight). These findings together support the hypothesis that differences in aluminum concentrations may be related to diet, feeding behavior and feeding locations. As mentioned previously, gray whales feed primarily on benthic prey using suction to engulf sediments and prey from the ocean bottom (Nerini, 1984). Bowhead whales are water column feeders and have minimal exposure to sediment-associated aluminum compared to gray whales (Lowry, 1993; Krone et al., 1999).

The concentration of mercury in the gray whale livers was comparable to the relatively low levels found in other mysticetes such as bowhead (17-110 ng/g, wet weight) (Krone et al., 1999) and minke whales (61-390 $\mathrm{ng} / \mathrm{g}$, wet weight) (Honda et al., 1987). These findings are consistent with the greater bioaccumulation of mercury in odontoceti that often feed at higher trophic levels than mysteceti that feed predominantly on invertebrates. The mean concentrations of mercury in liver and kidney of the gray whales sampled in this study were relatively low when compared to odontecetes (e.g., O'Shea and Brownell, 1994; Wagemann and Muir, 1984). The range in mean concentrations of mercury in liver of odontocete species, for example, porpoises and narwhals (Monodon monoceros), from several studies was 700-31 000, and in kidney 680-3600 ng/g wet weight (Wagemann and Muir, 1984).

The mean selenium concentration of 1100 (140) ng/g wet weight in gray whale liver was comparable to the mean value in bowhead whale liver [1000 (98) ng/g wet weight]. The mean molar ratio of liver mercury to selenium $(1: 18)$ in the subsistence gray whales was much lower than the $1: 1$ ratio observed in many toothed whales and pinnipeds (e.g., Koeman et al., 1973; Meador et al., 1993). The ratio in gray whales was more comparable to that in bowhead, which was 1:40 (Krone et al., 1999). The bowhead whale findings (Krone et al., 1999) suggest that there is a baseline physiologic level of hepatic selenium (approximately $2500 \mathrm{ng} / \mathrm{g}$ wet weight) that remains constant until the mercury concentration exceeds this physiologic selenium level, at which point the selenium concentrations begin to rise in parallel with mercury (Krone et al., 1999). This would be consistent with the postulated detoxification role of selenium through formation of insoluble mercury selenide compounds (Augier et al., 1993).

The concentration of cadmium in gray whale livers was about 40 times lower than that in livers of subsistence bowhead whales taken in Alaska (Krone et al., 1999). Planktonic crustaceans (i.e., copepods, euphausiids), which are reported to contain relatively higher concentrations of cadmium and higher concentrations of mercury compared to fish (Honda et al., 1987) are a major component of the bowhead whale diet, unlike the gray whales which feed extensively on benthic crustaceans. These dietary differences may explain, in part, the differences in liver cadmium levels of the two baleen whale species.

The concentrations of nickel, copper, zinc and lead in liver tissue samples (Table 2) were similar to or somewhat lower than the concentrations of these elements in liver of bowhead whales (Krone et al., 1999) and minke whales harvested between 1980 and $1985(n=135)$ in Antarctica (Honda et al., 1987). The concentrations of nickel ranged from 20 to $140 \mathrm{ng} / \mathrm{g}$ wet weight, copper from 2300 to 9900 , zinc from 22000 to 65000 and lead from 28 to 650 in liver samples analyzed from these bowhead and minke whales. Overall, the concentrations of essential and non-essential elements found in tissues of gray whales were well below the levels considered to be toxic to terrestrial animals (e.g., mercury $>50000$; cadmium > 50000; zinc > 120000; lead > $5000 \mathrm{ng} / \mathrm{g}$ wet weight) (Puls, 1988); however, the toxicity of elements to cetaceans is not well understood.

\section{Summary}

The present findings for juvenile gray whales sampled off their Bering Sea feeding grounds showed that the concentrations of a broad spectrum of anthropogenic contaminants were relatively low compared to other species of marine mammals that feed at higher trophic levels. The concentrations of OCs were significantly lower on a lipid basis in juvenile subsistence animals than previously reported in juvenile stranded whales. This may be due to the retention of OCs in blubber as lipid stores are mobilized for energy and total lipid levels decrease, rather than markedly increased exposure or differences in diet (Krahn et al., 2001). The results for most trace elements showed that the concentrations in tissues were low and less than concentrations that are considered to be of toxicological concern. The profile of elements was influenced by the feeding habits of gray whales, for example, aluminum in stomach contents was high compared to other marine mammal species, which is consistent with the ingestion of sediment during feeding. These data for concentrations of contaminants 
in subsistence whales substantially increase the information available for presumably healthy gray whales.

\section{Acknowledgements}

This study was supported, in part, by the National Marine Fisheries Service's Marine Mammal Health and Stranding Response Program. Additionally, we thank Donald W. Brown and his colleagues in our environmental chemistry program for assistance in chemical and data analyses. We also thank Daniel Lomax and Gina Ylitalo for reviewing the manuscript.

\section{References}

Abacus Concepts, 1989. SuperANOVA. Abacus Concepts, Inc., Berkeley, California.

Aguilar, A., 1985. Compartmentation and reliability of sampling procedures in organochlorine pollution surveys of cetaceans. Residue Rev. 95, 91-114.

Aguilar, A., Borrell, A., 1988. Age- and sex-related changes in organochlorine compound levels in fin whales (Balaenoptera physalus) from the Eastern North Atlantic. Mar. Environ. Res. 25, 195-211.

Aguilar, A., Borrell, A., 1990. Patterns of lipid content and stratification in the blubber of fin 10 whales (Balaenoptera physalus). J. Mammal. 71 (4), 544-554.

Aguilar, A., Borrell, A., 1994. Reproductive transfer and variation of body load of organochlorine pollutants with age in fin whales (Balaenoptera physalus). Arch. Environ. Contam. Toxicol. 27, 546-554.

Ash, C.E., 1956. Variation in blubber thickness with length in fin whales. Norsk Havalfangst-tidende 45, 550-554.

Augier, H., Park, W.K., Ronneau, C., 1993. Mercury contamination of the striped dolphin Stenella coeruleoalba from the French Mediterranean coasts. Mar. Pollut. Bull. 26 (6), 306311.

Ballschmiter, K., Zell, M., 1980. Analysis of polychlorinated biphenyls with capillary gas chromatography. Fresenius Z. Anal. Chem. 302, 20-31.

Beckmen, K.B., Ylitalo, G.M., Towell, R.G., Krahn, M.M., O’Hara, T.M., Blake, I.E., 1999. Factors affecting organochlorine contaminant concentrations in milk and blood of northern fur seal (Callorhinus ursinus) dams and pups from St. George Island, Alaska. Sci. Total Environ. 231, 183-200.

Calambokidis, J., 1992. Gray whale deaths in Puget Sound: a perspective. In: Puget Sound Notes 1992, pp. 5-7.

Calambokidis, J., Steiger, G.H., Everson, J.R., Cubbage, J.C., Osborne, R.W., 1991. Gray whales in Puget Sound and the Strait of Juan du Fuca. In: Puget Sound Research '91. Puget Sound Water Quality Authority, Seattle, WA.

Darling, J.D., 1984. Gray whales off Vancouver Island, British Columbia. In: Jones, M.L., Swartz, S.L., Leatherwood, S. (Eds.), The Gray Whale (Eschrichtius robustus). Academic Press, New York, pp. 267-287.

Fujise, Y., Honda, K., Tatsukawa, R., Mishima, S., 1988. Tissue distribution of heavy metals in Dall's porpoise in the northwestern Pacific. Mar. Pollut. Bull. 19 (5), 226230.

Fukushima, M., Kawai, S., 1980. Variation of organochlorine residue concentration and burden in striped dolphin (Stenella coeruleoalba) with growth. In: Fujiyama, T. (Ed.), Studies on the Levels of Organochlorine Compounds and Heavy Metals in Marine Organisms. University of Ryukus, Okinawa, pp. 97-114.

Goyer, R.A., 1986. Toxic effects of metals. In: Klaassen, C.D., Amdur, M.O., Doull, J. (Eds.), Casarett and Doull's Toxicology: The Basic Science of Poisons. Macmillan Publishing Co., Inc., New York, pp. 582-635.

Haley, D., 1986. Marine Mammals of Eastern North Pacific and Arctic Waters. Pacific Search Press, Seattle, Washington.

Highsmith, R.C., Coyle, K.O., 1992. Productivity of Arctic amphipods relative to gray whale energy requirements. Mar. Ecol-Prog. Ser. 83, 141-150.

Honda, K., Yamamoto, Y., Kato, H., Tatsukawa, R., 1987. Heavy metal accumulations and their recent changes in southern minke whales, Balaenoptera acutorostrata. Arch. Environ. Contam. Toxicol. 16, 209-216.

Kawai, S., Fukushima, M., Miyazaki, N., Tatsukawa, R., 1988. Relationship between lipid composition and organochlorine levels in the tissue of striped dolphin. Mar. Pollut. Bull. 19 (3), 129-133.

Koeman, J.H., Peters, W.H.M., Koudstaal-Hol, C.H.M., Tjioe, P.S., Goeij, J.J.M., 1973. Mercury-selenium correlations in marine mammals. Nature 245, 385-386.

Krahn, M.M., Wigren, C.A., Pearce, R.W., Moore, L.K., Bogar, R.G., MacLeod Jr., W.D., Chan, S.-L., Brown, D.W., 1988. Standard Analytical Procedures of the NOAA National Analytical Facility, 1988. New HPLC Cleanup and Revised Extraction Procedures for Organic Contaminants. US Department of Commerce, NOAA Technical Memorandum NMFS F/NWC153, pp. 1-52.

Krahn, M.M., Burrows, D.G., Stein, J.E., Becker, P.R., Schantz, M.M., Muir, D.C.G., O'Hara, T.M., Rowles, T., 1999. White whales (Delphinapterus leucas) from three Alaskan stocks - concentrations and patterns of persistent organochlorine contaminants in blubber. J. Cetacean Res. Manage. 1 (3), 239-249.

Krahn, M.M., Ylitalo, G.M., Burrows, D.G., Calambokidis, J., Moore, S.E., Gosho, M., Gearin, P., Plesha, P.D., Brownell, R.L., Blokhin, S.A., Tilbury, K.L., Rowles, T., Stein, J.E., 2001. Organochlorine contaminant concentrations and lipid profiles in eastern North Pacific gray whales (Eschrichtius robustus). J. Cetacean Res. Manage. 3 (1), 19-29.

Krone, C.A., Robisch, P.A., Tilbury, K.L., Stein, I.E., Mackey, E.A., Becker, P.R., O’Hara, T.M., Philo, L.M., 1999. Elements in liver tissues of bowhead whales (Balaena mysticetus). Mar. Mammal Sci. 15 (1), 123-142.

Kuehl, D.W., Haebler, R., 1995. Organochlorine, organobromine, metal, and selenium residues in bottlenose dolphins (Tursiops truncatus) collected during an unusual mortality event in the Gulf of Mexico, 1990. Arch. Environ. Contam. Toxicol. 28, 494-499.

Lowry, L.F., 1993. Foods and feeding ecology. In: Burns, J.J., Montague, J.J., Cowles, C.J. (Eds.), The Bowhead Whale. The Society for Marine Mammalogy, Kansas, pp. 201-238. 
Mackintosh, N.A., Wheeler, J.F.G., 1929. Southern blue and fin whales. Discovery Rep. 1, 257-540.

Mallonee, J.S., 1991. Behavior of gray whales (Eschrichtius robustus) summering off the northern California coast, Patrick's Point to Crescent City. Can. J. Zool. 69, 681690.

Meador, J.P., Varanasi, U., Robisch, P.A., Chan, S.-L., 1993. Toxic metals in pilot whales (Globicephala melaend) from strandings in 1986 and 1990 on Cape Cod, Massachusetts. Can. J. Fish. Aquat. Sci. 50, 2698-2706.

Mizue, K., Murata, T., 1951. Biological investigations on the whales caught by the Japanese Antarctic whaling fleets season 1949-1950. Sci. Rep. Whales Res. Inst. 6, 73131.

Moore, S.E., Grebmeier, J.M., Davis, J.M., 2000. Gray whale foraging habits in the northern Bering Sea: a GIS-based retrospective summary. In: Fifty-second Annual Meeting of the International Whaling Commission. International Whaling Commission, Adelaide, Australia.

Nerini, M., 1984. A review of gray whale feeding ecology. In: Jones, M.L., Swartz, S.L., Leatherwood, S. (Eds.), The Gray Whale (Eschrichtius robustus). Academic Press, Inc., New York, NY, pp. 423-448.

Nishiwaki, M., Ohe, T., 1951. Biological investigation on blue whales (Balaenoptera musculus) and fin whales (Balaenoptera physalus) caught by the Japanese Antarctic whaling fleets. Sci. Rep. Whales Res. Inst. 5, 91-167.

Norman, S.A., Muto, M.M., Rugh, D.J., Moore, S.E., 2000. Gray whale strandings in 1999 and a review of stranding records in 1995-1998. SC/52/AS5, International Whaling Commission.

O’Shea, T.J., Brownell Jr., R.L., 1994. Organochlorine and metal contaminants in baleen whales: a review and evaluation of conservation implications. Sci. Total Environ. 154, 179-200.

Patten, D.R., Samaras, W.F., 1977. Unseasonable occurrences of gray whales. Bull. South California Acad. Sci. 76, 206208.

Puls, R., 1988. Mineral Levels in Animal Health: Diagnostic Data. Aherpa International, Clearbrook, British Columbia.

Rice, D.W., Wolman, A.A., 1971. The Life History and Ecology of the Gray Whale (Eschrichtius robustus). American Society of Mammalogists, Oklahoma City.

Robisch, P.A., Clark Jr., R.C., 1993. Sampling and Analytical Methods of the National Status and Trends Program, National Benthic Surveillance and Mussel Watch Projects 1984-1992. Comprehensive Descriptions of Elemental Analytical Methods. Sample Preparation and Analyses of Trace Metals by Atomic Absorption Spectrocopy, vol. III. US Department of Commerce, NOAA Technical Memorandum NOS ORCA 71, pp. 111-150.

Schaffer, H.A., Gossett, R.W., Ward, C.F., Westcott, A.M., 1984. Chlorinated hydrocarbons in marine mammals. In: Bascom, W. (Ed.), Biennial Report 1983-1984. Southern Californian Coastal Water Research Project, Long Beach, pp. 109-114.
Slijper, E.J., 1954. On the importance of measuring the thickness on the layer of blubber in whales. Norsk Havalfangst-tidende $43,510-516$.

Sloan, C.A., Adams, N.G., Pearce, R.W., Brown, D.W., Chan, S.-L., 1993. Sampling and Analytical Methods of the National Status and Trends Program, National Benthic Surveillance and Mussel Watch Projects 1984-1992. Comprehensive Descriptions of Trace Organic Analytical Methods. Northwest Fisheries Science Center Organic Analytical Procedures, vol. IV. US Department of Commerce, NOAA Technical Memorandum NOS ORCA 71, pp. 53-98.

Subramanian, A., Tanabe, S., Tatsukawa, R., 1988. Use of organochlorines as chemical tracers in determining some reproductive parameters in Dalli-type Dall's porpoise Phocoenoides dalli. Mar. Environ. Res. 25, 161-174.

Sumich, J.L., 1984. Gray whales along the Oregon coast in summer, 1977-1980. Murrelet 65, 33-40.

Tilbury, K.L., Stein, I.E., Meador, J.P., Krone, C.A., Chan, S.-L., 1997. Chemical contaminants in harbor porpoise (Phocoena phocoena) from the north Atlantic coast: tissue concentrations and intra- and inter-organ distribution. Chemosphere 34 (9/10), 2159-2181.

Tilbury, K.L., Adams, N.G., Krone, C.A., Meador, J.P., Early, G., Varanasi, U., 1999. Organochlorines in stranded pilot whales (Globicephala melaena) from the Coast of Massachusetts. Arch. Environ. Contam. Toxicol. 37, 125134.

Varanasi, U., Stein, J.E., Reichert, W.L., Tilbury, K.L., Krahn, M.M., Chan, S.-L., 1992. Chlorinated and aromatic hydrocarbons in bottom sediments, fish and marine mammals in US coastal waters: laboratory and field studies of metabolism and accumulation. In: Walker, C.H., Livingstone, D.R. (Eds.), Persistent Pollutants in Marine Ecosystems. Pergamon Press, New York, NY, pp. 83-115.

Varanasi, U., Stein, J.E., Tilbury, K.L., Meador, J.P., Sloan, C.A., Brown, D.W., Calambokidis, J., Chan, S.-L., 1993. Chemical Contaminants in Gray Whales (Eschrichtius robustus) Stranded in Alaska, Washington, and California, USA. US Department of Commerce, NOAA Technical Memorandum NMFS NWFSC 11, pp. 1-115.

Varanasi, U., Stein, J.E., Tilbury, K.L., Meador, J.P., Sloan, C.A., Clark Jr., R.C., Chan, S.-L., 1994. Chemical contaminants in gray whales (Eschrichtius robustus) stranded along the west coast of North America. Sci. Total Environ. 145, $29-53$.

Wagemann, R., Muir, D.C.G., 1984. Concentration of heavy metals and organochlorines in marine mammals of northern waters: overview and evaluation. Canadian Technical Report of Fisheries and Aquatic Sciences, no. 1279, Department of Fisheries and Oceans.

Wagemann, R., Stewart, R.E.A., Beland, P., Desjardins, C., 1990. Heavy metals and selenium in tissues of beluga whales, Delphinapterus leucas, from the Canadian Arctic and St. Lawrence Estuary. Can. J. Fish. Aquat. Sci. 224, 191-206.

Wolman, A.A., Wilson Jr., A.J., 1970. Occurrence of pesticides in whales. Pestic. Monit. J. 4 (1), 8-10. 